\title{
Review of the efficacy and safety of cryoablation for the treatment of small renal masses
}

\author{
Anil Kapoor, MD, FRCSC; ${ }^{*}$ Naji J Touma, MD; ${ }^{\dagger}$ Regina El Dib, PhD
}

*Chair, GU Oncology Program, Juravinski Cancer Centre, Professor of Surgery (Urology), St. Joseph's Healthcare, McMaster University, Hamilton, ON; †Assistant Professor, Department of Urology, Queen's

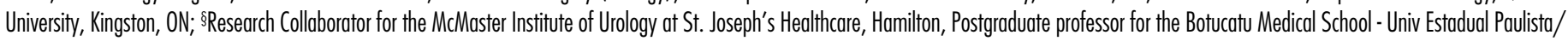
Unesp, Brazil

Cite as: Can Urol Assoc J 2013;7(1):E38-E43. http://dx.doi.org/10.5489/cuaj.12018

\section{Abstract}

Purpose: Small renal masses are increasingly being discovered incidentally on imaging for another reason. The standard of care of these masses involves excision by open or laparoscopic techniques. Recently, ablative techniques, such as radiofrequency ablation (RFA) and cryoablation, have taken a more prominent role in the treatment algorithm of these masses. We evaluate the effectiveness and safety of cryoablation to treat renal tumours.

Methods: A review of the literature was conducted. There was no language restriction. Studies were obtained from the following sources: the Cochrane Library, PUBMED, EMBASE and LILACS.

Results: There was no clinical trial identified in the literature. Thus, we described the results from 23 case series and retrospective studies with a reasonable sample size (number of reported patients in each study $\geq 30$ ), with a total of 2104 analyzed tumours from 2038 patients. There was wide variability in the outcomes reported, but success rates were generally good. Follow-up was generally short, but some series reported outcomes at 5 years. The most common complications reported were hemorrhage (some of the patients requiring transfusion), perinephric hematoma and urine leaks.

Conclusion: Cryoablation presents a feasible treatment for patients with small renal masses. Only short-term data are available and, as such, meaningful conclusions regarding long-term cancer control cannot be made. More rigorous studies are needed.

\section{Introduction}

In Canada, the incidence of renal cancer is 4500 new cases per year, with 1500 dying of the disease. ${ }^{1}$ Small renal masses are increasingly being discovered incidentally on imaging for another reason. ${ }^{2,3}$ The natural history of these incidentally discovered masses remains unclear. When surgically excised, the masses are shown to be $70 \%$ to $80 \%$ renal cell carcinoma (RCC), and the rest are benign. ${ }^{4-7}$

When technically feasible, the standard of care for these masses has been partial and radical nephrectomy. Local and distant oncological control has been well-established with surgical excision. ${ }^{8}$ In the last 10 years, a minimally invasive approach with laparoscopy has largely supplanted open surgery. The question of whether in situ ablative technologies ${ }^{9,10}$ can replace excision for the treatment of small renal tumours remains unanswered. The main advantage of ablative techniques would be to offer treatment to patients who are otherwise not candidates for invasive extirpative techniques. ${ }^{11,12}$

Several ablative technologies have been investigated, including cryoablation (CA), radiofrequency ablation (RFA), microwave, ${ }^{13}$ high-intensity focused ultrasound, ${ }^{14,15}$ laser interstitial thermotherapy, ${ }^{16}$ microwave thermotherapy and radiosurgery.

Cryoablation has been used to treat human cancers since the 19th century, with the use of ice-salt mixtures to treat cervical and breast cancers. ${ }^{17}$ In urology, CA has long been used to treat prostatic diseases: first for benign prostatic hyperplasia in the $1960 \mathrm{~s},{ }^{18}$ and later for prostate cancer. ${ }^{19}$ Freezing and thawing causes alteration in various biological processes that ultimately result in cell death. CA targets and kills specific cells and spares surrounding tissue, which can be critical in patients with compromised renal function and small RCC.

In the last few years, several series have reported the results of CA for small renal masses with short to intermediate follow-up. A meta-analysis of case series studies evaluating CA and RFA showed no significant difference regarding clinical efficacy (the authors defined it as cancer-specific survival rate, radiographic success, no evidence of local tumour progression or distant metastases) and intraoperative and postoperative complications rates between both interventions. ${ }^{20}$

In this review, we examine the efficacy of CA to treat renal tumours. The efficacy of this technology in terms of oncological control and prevention of local recurrence and metastasis is reviewed. Complications and safety concerns as they relate to $\mathrm{CA}$ will also be reported. 


\section{Methods}

There was no language restriction. Trials were obtained from the following sources: Cochrane Central Register of Controlled Trials (Central, The Cochrane Library, issue 1, 2011), US National Library of Medicine (PUBMED; 19662011), Excerpta Medica database (EMBASE; 1980-2011), Literatura Latino-Americana e do Caribe em Ciências da Saúde (LILACS; 1982-2011) and the Current Controlled Trials to identify all studies regarding cryoablation in RCC.

The databases were searched using a comprehensive search strategy for kidney cancers and cryoablation, along with $\mathrm{MeSH}$ and text words, including an exhaustive list of synonyms (Table 1). The search strategy was adapted for each database to achieve more sensitivity. The bibliographic references in relevant review articles were also examined for eligible trials. The search was performed up to January 2011. In total, 696 titles were identified from the electronic databases. After screening by title and then abstract by two reviewers, full paper copies for 64 studies that were potentially eligible for inclusion in the review were obtained. The remaining 632 were off-topic, animal research, narrative reviews or in vitro studies. No randomized trials were identified, and therefore, the results from case series and retrospective studies with a reasonable sample size (number of reported patients in each study $\geq 30$ ) were included in this review.

The following clinical outcome measurements were examined: cancer-specific survival, radiographic success, tumour recurrence, local tumour progression or distant metastases, need for repeat ablation, complications, adverse events and renal function.

\section{Results}

Table 2 summarizes the characteristics of published studies on CA. Most patients undergoing CA had T1a disease with a mean tumour size ranging from 1.8 to $4.2 \mathrm{~cm}$. The laparoscopic approach was the most commonly used approach, although the percutaneous and open approaches were also employed. The maximum mean and median follow-up reported was 45.7 months and 36 months, respectively.

Table 3 shows the clinical outcomes and complications reported in the examined CA studies. Cancer-specific survival, recurrence tumour rates and radiographic or technical success were the most commonly used outcomes to evaluate oncological control. Lack of contrast enhancement, decrease in tumour size, or lack of growth on serial imaging were considered signs of complete and successful ablation. The maximal and minimal percentage of cancer-specific survival reported was $100 \%$ and $84.3 \%$ in a follow-up of 11.4 months (median) and 64 months (mean), respectively. The most commonly reported complications were: hemor-
Table 1. Summary of the bibliographic search strategies for type of clinical situation and intervention of interest.

(Kidney Neoplasm) OR (Renal Neoplasms) OR (Renal Neoplasm) OR (Kidney Neoplasms) OR (Cancer of Kidney) OR (Kidney Cancers) OR (Renal Cancer) OR (Renal Cancers) OR (Cancer of the Kidney) OR (Kidney Cancer) OR (Kidney Cancers) OR (Renal masses) OR (Renal cell carcinoma)) AND (Cryosurgeries OR Cryosurgery OR Cryoablation OR Cryoablations OR Cryotherapy)

rhage (some of the patients requiring transfusion), perinephric hematoma and urinary leak. Nonetheless, the procedures seem to be well-tolerated.

\section{Discussion}

The principle of tissue freezing with CA involves the Joule Thomson phenomenon, whereby rapid cooling results from the rapid phase change of a highly compressed liquid expanding through a restricted orifice to a gaseous state. The mechanism of cellular injury by CA is a result of direct and indirect physiological processes. When the extracellular fluid freezes, there is an increase in osmotic pressure in the extracellular compartment. The resulting fluid shift causes cellular dehydration, accumulation of toxins within the cells, change in $\mathrm{pH}$ and denaturation of proteins. The disruption of the cellular membrane leads to crystallization of the intracellular fluid. In addition, endothelial damage leads to ischemia, thrombosis and coagulative necrosis, synergizing cell death. ${ }^{21,22}$

Imaging with computed tomography (CT) scans or magnetic resonance imaging (MRI) is the typical follow-up for cryoablated tumours, although a specific follow-up protocol has not been widely accepted. Tumour size may increase in early follow-up due to peri-tumour hemorrhage, and the difficulty in determining tumour margin from surrounding fibrosis and stranding. ${ }^{23-25}$ However, any enhancement on CT scan $(>10 \mathrm{HU})$ or a progressive increase in tumour size is a sign of inadequate ablation. On MRI, $61 \%$ of adequately treated tumours are isointense to renal parenchyma on $\mathrm{T} 1$-weighted images, and 95\% are either isointense or hypointense on T2 weighted images. ${ }^{26}$ It remains unclear if radiological follow-up either by CT scan or MRI constitutes an adequate surrogate for local cancer control. Preoperative biopsies of these renal masses were uncommon in most series, even less so postoperative biopsies. One exception was the series by Gill and colleagues; the authors routinely performed biopsies at 6 months post-CA. In this series, 2 out of 56 tumours proved to be positive at 6 months post-CA, for a rate of $3.6 \% .{ }^{27}$ In a prostate cancer model, where CA has been more extensively studied, positive biopsies postCA have been found in up to $23.1 \%$ of patients in a postradiotherapy CA model. ${ }^{28}$ While it may be stipulated that the prostate cancer model is not necessarily an apt comparison given the multi-focal nature of prostate cancer versus a solid 
Table 2. Case series and retrospective studies on cryoablation for renal tumours

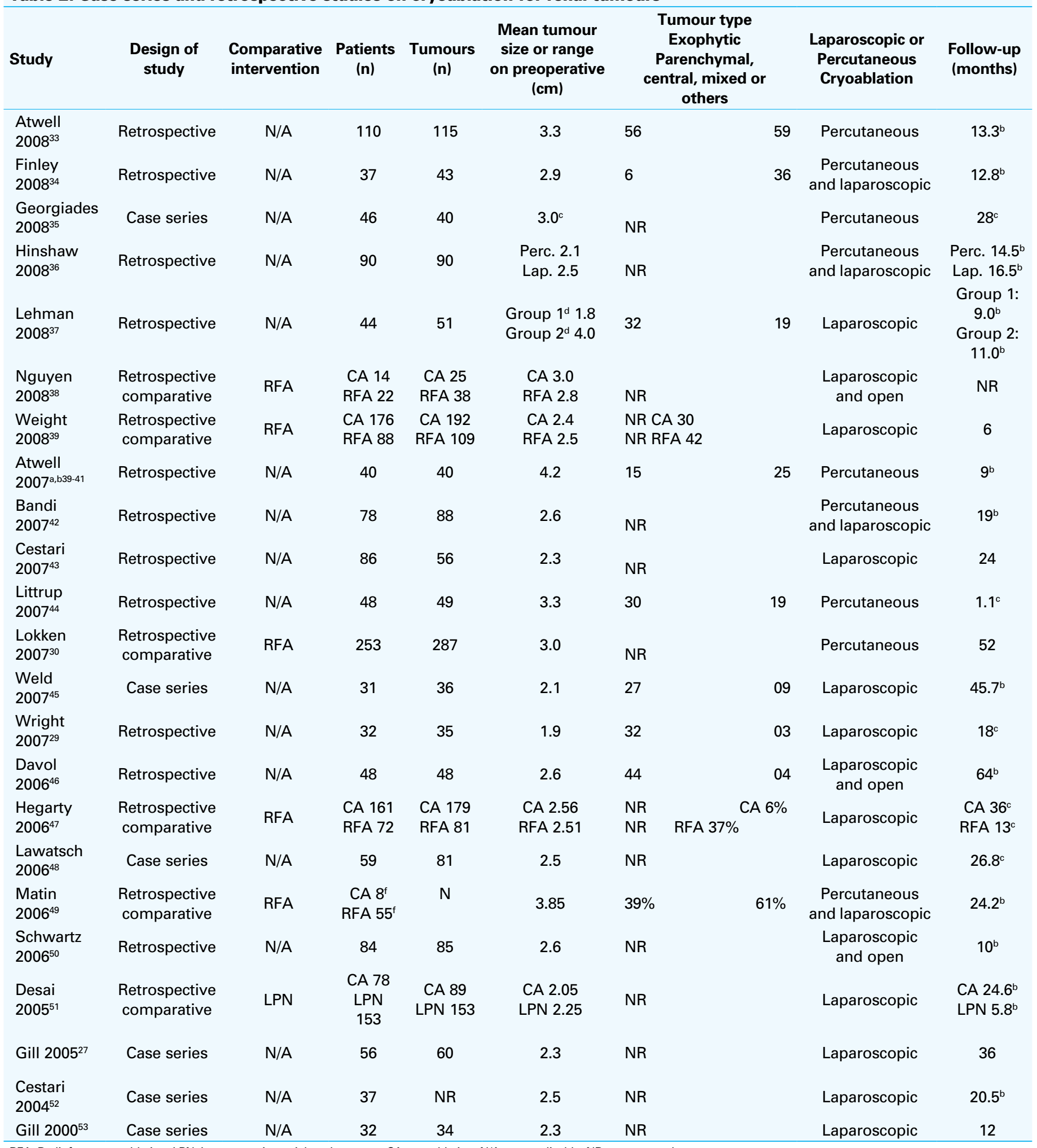

RFA: Radiofrequency ablation; LPN: Laparoscopic partial nephrectomy; CA: cryoablation; N/A: not applicable; NR: not reported.

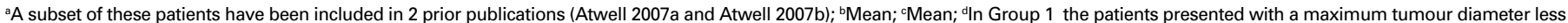

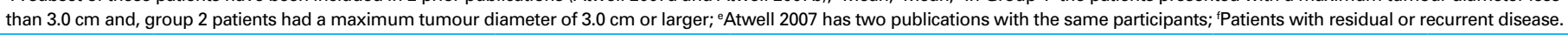




\section{Table 3. Clinical outcome and complications of each included studied}

\begin{tabular}{|c|c|c|c|c|}
\hline \multirow[b]{2}{*}{ Study } & \multicolumn{2}{|l|}{ Outcomes } & \multicolumn{2}{|c|}{ Complications* } \\
\hline & Clinical outcome studied & $\begin{array}{l}\text { Occurrence } \\
(\%)\end{array}$ & Major complications & Minor complications \\
\hline $\begin{array}{l}\text { Atwell } \\
2008^{33}\end{array}$ & 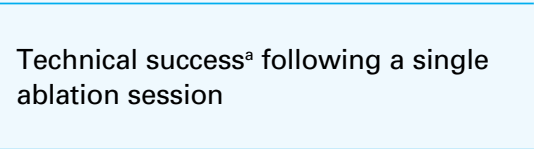 & $97 \%$ & $\begin{array}{l}\text { Worsening preexisting hypert } \\
(0.90 \%) \text {; large hematomas req } \\
\text { red blood cells }(2.7 \%) \text {; pulmon } \\
\text { requiring ureteral stent placen }\end{array}$ & $\begin{array}{l}\text { ension }(0.90 \%) \text {; pulmonary edema } \\
\text { uiring angiography and transfusion of } \\
\text { ary embolus }(0.90 \%) \text { and hematuria } \\
\text { eent }(090 \%)\end{array}$ \\
\hline \multirow{2}{*}{$\begin{array}{l}\text { Finley } \\
2008^{34}\end{array}$} & $\begin{array}{l}\text { CSS among patients with biopsy } \\
\text { proven RCC during a median follow-up } \\
\text { of } 11.4 \text { and } 13.4 \text { months }\end{array}$ & $\begin{array}{l}100 \% \text { and } \\
100 \%\end{array}$ & \multirow{2}{*}{\multicolumn{2}{|c|}{$\begin{array}{l}\text { Hemorrhage requiring transfusion }(13.5 \%) \text {; blood transfusions } \\
(16.2 \%) \text {; internal jugular vein thrombus }(2.7 \%) \text {; small bowel injury } \\
(2.7 \%) \text { and loss of kidney }(2.7 \%)\end{array}$}} \\
\hline & $\begin{array}{l}\text { Treatment failure rate }{ }^{b} \text { among patients } \\
\text { with biopsy proven } \mathrm{RCC} \text { during a } \\
\text { median follow-up of } 11.4 \text { and } 13.4 \\
\text { months }\end{array}$ & $\begin{array}{l}5.3 \% \text { and } \\
4.2 \%\end{array}$ & & \\
\hline \multirow{2}{*}{$\begin{array}{l}\text { Georgiades } \\
2008^{35}\end{array}$} & Technical success $^{c}$ & $100 \%$ & \multirow{2}{*}{\multicolumn{2}{|c|}{$\begin{array}{l}\text { Silent, small perinephric hematoma; large, painful perinephric } \\
\text { hematomas; intercostal nerve injury; genitofemoral nerve injury; }\end{array}$}} \\
\hline & Overall CR ${ }^{\mathrm{d}}$ & $97.5 \%$ & & \\
\hline $\begin{array}{l}\text { Hinshaw } \\
2008^{36}\end{array}$ & Effectiveness rate ${ }^{e}$ for laparoscopic CA & $93.3 \%$ & $\begin{array}{l}\text { Severe respiratory distress } \\
(1.1 \%) \text {; intraoperative } \\
\text { bowel injury }(1.1 \%) \text { and } \\
\text { postoperative atrial } \\
\text { fibrillation }(1.1 \%)\end{array}$ & $\begin{array}{l}\text { Asymptomatic perinephric } \\
\text { hematoma; asymptomatic and } \\
\text { self-limited urine leak; self-limited } \\
\text { flank paresthesia and neuralgia; and } \\
\text { intercostal neurapraxia }(4.4 \%) \text {. }\end{array}$ \\
\hline \multirow[b]{2}{*}{$\begin{array}{l}\text { Lehman } \\
2008^{37}\end{array}$} & \multirow[b]{2}{*}{ Tumour recurrences } & $\begin{array}{l}\text { Group 1: } \\
\quad 0 \%\end{array}$ & \multirow{2}{*}{\multicolumn{2}{|c|}{$\begin{array}{l}\text { Group 1: no complications }(0 \%) \\
\text { Group } 2(62 \%) \text { : mortality }(4.5 \%) \text {; cerebrovascular accident; } \\
\text { myocardial infarction; pulmonary embolism and; hemorrhage with } \\
\text { blood transfusion }\end{array}$}} \\
\hline & & $\begin{array}{l}\text { Group } 2: \\
4.8 \%\end{array}$ & & \\
\hline \multirow{2}{*}{$\begin{array}{l}\text { Nguyen } \\
2008^{38}\end{array}$} & \multirow{2}{*}{ Tumour recurrences } & \multirow{2}{*}{$\begin{array}{l}\text { CA } 7.4 \% \\
\text { RFA } 25 \%\end{array}$} & $\begin{array}{l}\text { Intraoperative complications: } \\
\text { CA: renal arterial injury } \\
(21 \%) \text {; } \\
\text { RFA: no major intraoperative } \\
\text { complications reported on } \\
\text { this group }(0 \%)\end{array}$ & $\begin{array}{l}\text { Intraoperative complications: } \\
\text { CA: diaphragmatic injury }(7.1 \%) \text {; } \\
\text { pleurotomy (requiring chest tube) } \\
\text { (7.1\%) and peritoneotomy }(21 \%) \\
\text { RFA: no major intraoperative } \\
\text { complications reported on this } \\
\text { group }(0 \%)\end{array}$ \\
\hline & & & $\begin{array}{l}\text { Postoperative complications: } \\
\text { CA: no major postoperative } \\
\text { complications reported on } \\
\text { this group }(0 \%) \text {. } \\
\text { RFA: no major postoperative } \\
\text { complications reported on } \\
\text { this group }(0 \%) \text {. }\end{array}$ & $\begin{array}{l}\text { Postoperative complications: } \\
\text { CA: urinary leak and anephric state } \\
\text { (7.1\%). } \\
\text { RFA: no major postoperative } \\
\text { complications reported on this } \\
\text { group }(0 \%) .\end{array}$ \\
\hline \multirow{2}{*}{$\begin{array}{l}\text { Weight } \\
2008^{39}\end{array}$} & $\begin{array}{l}\text { Radiographic success }{ }^{f} \text { at } 6 \text {-months } \\
\text { follow-up }\end{array}$ & $\begin{array}{l}\text { CA } 90 \% \\
\text { RFA } 85 \%\end{array}$ & \multirow{2}{*}{ NR } & \multirow{2}{*}{ NR } \\
\hline & $\begin{array}{l}\text { Radiographic success }{ }^{f} \text { with biopsy and } \\
6 \text {-months imaging }\end{array}$ & $\begin{array}{l}\text { CA } 89 \% \\
\text { RFA } 81 \%\end{array}$ & & \\
\hline $\begin{array}{l}\text { Atwell } \\
2007^{\mathrm{a}, \mathrm{b} 40,41}\end{array}$ & Technical success ${ }^{g}$ & $95 \%$ & \multicolumn{2}{|c|}{$\begin{array}{l}\text { Large hemorrhage and transient renal failure (necessitated } \\
\text { temporary dialysis) }(2.5 \%)\end{array}$} \\
\hline $\begin{array}{l}\text { Bandi } \\
2007^{42}\end{array}$ & Overall, $\mathrm{CSS}^{\mathrm{h}}$ and RFS rates & $\begin{array}{l}88.5 \% \\
100 \% \text { and } \\
98.7 \% \\
\text { respectively }\end{array}$ & \multicolumn{2}{|c|}{$\begin{array}{l}\text { Atrial fibrillation }(1.2 \%) \text {; respiratory failure }(1.2 \%) \text { and; urine leak } \\
(1.2 \%) \text {; bleeding }(1.2 \%) \text {; bowel injury }(1.2 \%) \text {; symptomatic perirenal } \\
\text { haematoma }(1.2 \%) \text { and neurophatic pain }(1.2 \%)\end{array}$} \\
\hline \multicolumn{5}{|c|}{ 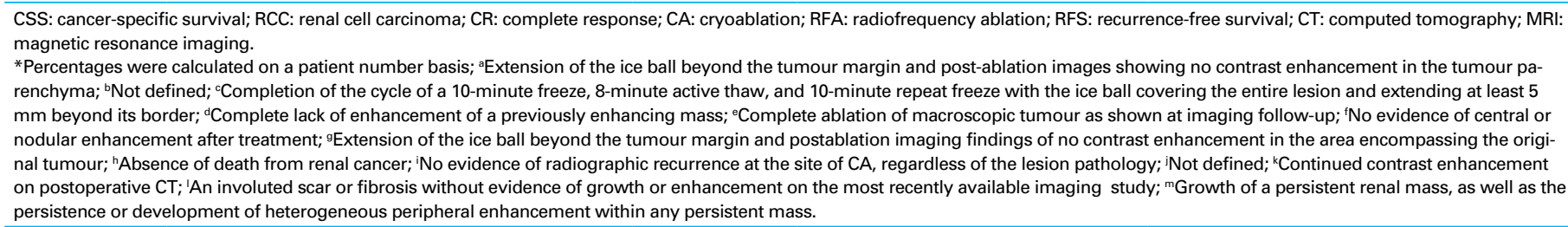 } \\
\hline
\end{tabular}


Table 3. Clinical outcome and complications of each included studied (cont'd)

\begin{tabular}{|c|c|c|c|}
\hline \multirow[b]{2}{*}{ Study } & \multicolumn{2}{|l|}{ Outcomes } & Complications* \\
\hline & Clinical outcome studied & $\begin{array}{l}\text { Occurrence } \\
(\%)\end{array}$ & Minor complications \\
\hline $\begin{array}{l}\text { Cestari } \\
2007^{43}\end{array}$ & NR & NR & $\begin{array}{l}\text { Minimal intraoperative blood loss }(100 \%) \text {; intraoperative renal } \\
\text { fracture }(2.3 \%) \text {; postoperative anemia }(8.1 \%) \text {; transitory hyperpyrexia } \\
(6.9 \%) \text {; hematoma }(2.3 \%) \text {; pulmonary edema }(1.1 \%) \text {; gross hematuria } \\
(1.1 \%) \text { and ureteropelvic junction obstruction }(1.1 \%)\end{array}$ \\
\hline $\begin{array}{l}\text { Littrup } \\
2007^{44}\end{array}$ & Technical success ${ }^{\mathrm{j}}$ & $98 \%$ & $\begin{array}{l}\text { Perinephric hematoma; hematuria and ureteral stricture. Major } \\
\text { and minor complications were seen in } 6 \% \text { and } 22 \% \text { procedures, } \\
\text { respectively }\end{array}$ \\
\hline $\begin{array}{l}\text { Lokken } \\
2007^{30}\end{array}$ & Occurrence of applicator track nodules & $\begin{array}{l}\text { CA } 2.7 \% \\
\text { RFA } 1.7 \%\end{array}$ & $\begin{array}{l}\text { CA: small perinephric hematoma }(0.3 \%) \\
\text { RFA: self-limited hematuria and small perinephric hematoma }(0.3 \%)\end{array}$ \\
\hline \multirow{3}{*}{$\begin{array}{l}\text { Weld } \\
2007^{45}\end{array}$} & 3-year CSS rate & $100 \%$ & \multirow{3}{*}{$\begin{array}{l}\text { Hemorrhage (3.2\%); urinary leak }(3.2 \%) \text {; gross hematuria }(3.2 \%) \text {; } \\
\text { ileus }(3.2 \%) \text {; perinephric urinoma }(3.2 \%) \text {; hydronephrosis }(3.2 \%) \text {; } \\
\text { blood clots }(3.2 \%) \text {; atrial fibrillation }(3.2 \%) \text {; and heart failure }(3.2 \%)\end{array}$} \\
\hline & $\begin{array}{l}\text { Mean increase of ablation zone size on } \\
\text { follow-up CT or MRI at } 3 \text { months }\end{array}$ & 14 & \\
\hline & $\begin{array}{l}\text { Mean decrease of ablation zone size on } \\
\text { follow-up CT or MRI at } 3 \text { months. }\end{array}$ & 71 & \\
\hline $\begin{array}{l}\text { Wright } \\
2007^{29}\end{array}$ & Treatment failures $^{k}$ & $6 \%$ & No major and minor complications were found $(0 \%)$ \\
\hline
\end{tabular}

Complete radiologic resolution' from a total of 40 patients available in the analysis

Davol Treatment failure ${ }^{m}$ from a total of 40 $2006^{46} \quad$ patients available in the analysis CSS rate in a total of 32 patients CSS rate after a single CA procedure in a total of 32 patients

Radiologic evidence of tumour recurrence or persistence of disease;

Hegarty

$2006^{47}$

CSS

\section{$85 \%$}

$12.5 \%$

$100 \%$

$84.3 \%$

CA $1.8 \%$

RFA $11.1 \%$

CA $98 \%$ at a median 3-year follow-up RFA $100 \%$ at 1-year median follow-up Lawatsch patient

Overall tumour recurrence rate per $2006^{48}$

Recurrence rate per lesion treated in patients with biopsy confirmed RCC

Overall survival rate in all patients from

Matin both groups

$2006^{49}$

2-year metastasis-free survival rate in all patients from both groups

No growth or evidence of recurrence on

Schwartz CT scan or MRI at 3 months

$2006^{50} \quad$ Radiographic enhancement after the procedure
There were no major adverse events found $(0 \%)$

There were 7 minor adverse events $(14.5 \%)$

CA: congestive heart failure $(0.62 \%)$; myocardial infarct $(0.62 \%)$; required thoracotomy for hemothorax (0.62\%)

RFA: no major complications

CA: required temporary ureteral stent insertion (1.2\%) were reported in the RFA group (0\%).
RFA: NR

\section{$5.9 \%$ in 34} patients

$5.1 \%$ for 38 lesions
Intraoperative complications: open surgery conversion (3.3\%); nephrectomy for bleeding (1.6\%); myocardial infarction (1.6\%); pneumothorax $(3,3 \%)$

Postoperative complications: perinephric hematoma (1.6\%); pulmonary embolus (1.6\%) and ileus (3.3\%)

\section{$82.5 \%$}

NR

NR

$97.4 \%$

$98.18 \%$

$3.6 \%$
Renal fracture (1.2\%); stroke (1.2\%) and hydronephrosis (1.2\%)

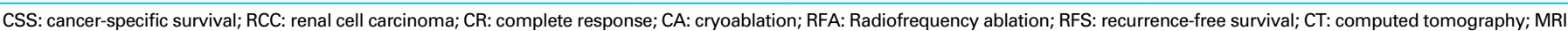
magnetic resonance imaging

*Percentages were calculated on a patient number basis; ${ }^{a}$ Extension of the ice ball beyond the tumour margin and post-ablation images showing no contrast enhancement in the tumour parenchyma; ${ }^{b}$ Not defined; ' Completion of the cycle of a 10-minute freeze, 8-minute active thaw, and 10-minute repeat freeze with the ice ball covering the entire lesion and extending at least 5

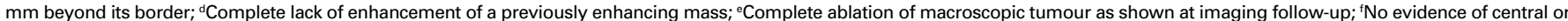

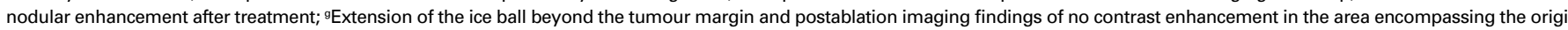

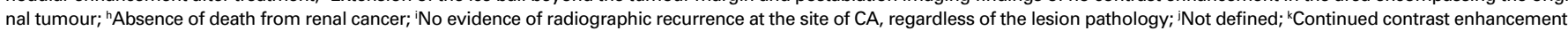

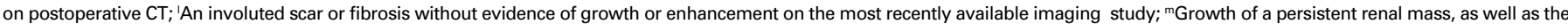
persistence or development of heterogeneous peripheral enhancement within any persistent mass. 


\begin{tabular}{|c|c|c|c|}
\hline \multirow[b]{2}{*}{ Study } & \multicolumn{2}{|l|}{ Outcomes } & Complications* \\
\hline & Clinical outcome studied & $\begin{array}{l}\text { Occurrence } \\
(\%)\end{array}$ & Major complications \\
\hline $\begin{array}{l}\text { Desai } \\
2005^{51}\end{array}$ & $\begin{array}{l}\text { Local recurrence at a mean follow-up } \\
\text { time of } 5.8 \text { months in LPN group and } \\
24.6 \text { months in CA group }\end{array}$ & $\begin{array}{c}\text { LPN } 0.6 \% \\
\text { CA } 3 \%\end{array}$ & $\begin{array}{l}\text { LPN associated with greater blood loss and a higher incidence of } \\
\text { delayed complications after hospital discharge compared with CA } \\
16.3 \% \text { versus } 2.2 \% \text {, respectively }\end{array}$ \\
\hline Gill $2005^{27}$ & $\begin{array}{l}\text { 3-year CSS (in a total of } 51 \text { patients with } \\
\text { sporadicunilateral renal tumour) }\end{array}$ & $98 \%$ & NR \\
\hline $\begin{array}{l}\text { Cestari } \\
2004^{52}\end{array}$ & $\begin{array}{l}\text { Mean reduction of cryolesions on MRI } 12 \\
\text { and } 18 \text { months of follow-up }\end{array}$ & $\begin{array}{l}73 \% \text { and } \\
76 \% \text { (in a } \\
\text { total number } \\
\text { of patients } \\
32 \text { and } 30 \\
\text { respectively) }\end{array}$ & $\begin{array}{l}\text { Transitory hyperthermia }(8.1 \%) \text {; hematoma }(8.1 \%) \text {; gross } \\
\text { hematuria }(2.7 \%) \text {; low postoperative pain }(100 \%) \text {; and } \\
\text { ureteropelvic junction obstruction }(2.7 \%)\end{array}$ \\
\hline Gill $2000^{53}$ & $\begin{array}{l}\text { Follow-up CT-directed needle negative } \\
\text { biopsies at } 3 \text { to } 6 \text { months in a total of } 23 \\
\text { patients }\end{array}$ & $100 \%$ & Perirenal hematoma (3.1\%) and herpes esophagitis $(3.1 \%)$ \\
\hline \multicolumn{4}{|c|}{ 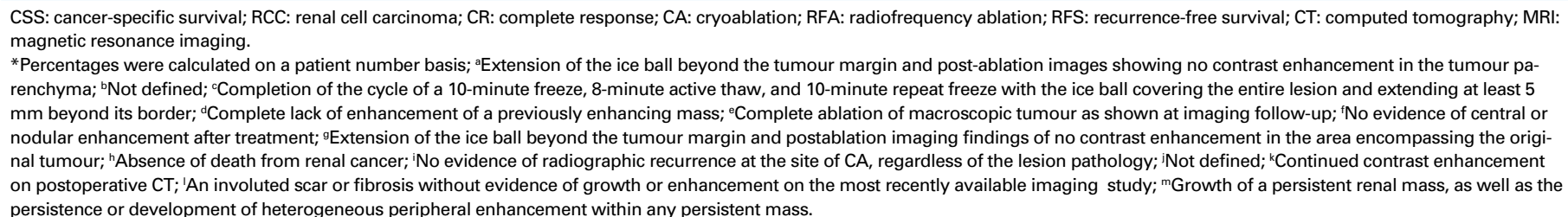 } \\
\hline
\end{tabular}

renal neoplasm, the lack of data confirming complete ablation and necrosis of the treated renal tumours leaves this technique open to question regarding equivalence to more accepted extirpative methods.

This review demonstrates a wide variability in the definition of outcomes (i.e., technical success, radiographic success, local recurrence and cancer specific survival). Cancerspecific survival can be as low as $84.3 \%,{ }^{29}$ and radiographic resolution as low as $71 \%,{ }^{30}$ even with relatively short followup intervals. When juxtaposed with the fact that $20 \%$ to $30 \%$ of small renal masses are found to be benign when excised, the true efficacy of CA should be assumed to be lower than reported. ${ }^{4-7}$ This highlights the need for longer follow-up, and for comparative trials with partial nephrectomy, or other ablative technologies, such as RFA.

CA is generally well-tolerated, but laparoscopic access is the most common technique. When compared to a partial nephrectomy, it has the advantage of not requiring hilar clamping, vascular and collecting system repair. However, a general anesthetic, and a pneumoperitoneum with all inherent complications remain essential. Hemorrhage, urinary leaks and injury to adjacent organs are all potential adverse events.

From a financial standpoint, CA compares favourably with other modalities for treatment of renal tumours. A financial analysis compared minimally invasive surgery procedures, such as laparoscopic cryoablation, laparoscopic partial nephrectomy and hand-assisted laparoscopic nephrectomy, versus conventional surgery. The open radical nephrectomy had higher total hospital costs (\$15 498), followed by laparoscopic partial nephrectomy (\$15 458). The lowest total hospital costs was laparoscopic cryoablation (\$10 105) for renal tumours smaller or equal than $3.5 \mathrm{~cm} .{ }^{31}$ However, in a more robust Markov model which factored the costs of follow-up and re-treatment, an immediate laparoscopic ablation procedure was found to be dominated by laparoscopic, and open partial nephrectomy for healthy patients less than 74 years old in terms of Quality Adjusted Life Years (QALY). Even in patients with multiple comorbidities, observation followed by possible delayed percutaneous ablation dominated immediate laparoscopic ablation. ${ }^{32}$

\section{Conclusions}

The results of this review show that cryoablation is a feasible treatment for patients with small renal masses. Longterm follow-up is lacking, but the available short-term data demonstrate a significant re-treatment rate. Given the lack of long-term follow-up, the technique should be reserved for elderly patients, or those with significant comorbidities, whose masses have demonstrated growth after a period of observation. Otherwise, partial nephrectomy remains the gold standard.

Continued research on cryoablation in the treatment of small renal tumours is needed, especially comparative trials with partial nephrectomy and other ablative technologies, such as RFA.

Competing interests: None declared.

This paper has been peer-reviewed. 


\section{References}

1. Canadian Cancer Society/National Cancer Institute of Canada. Canadian cancer statistics. Toronto: The Society, Inc.; 2005. www.cancer.ca. Accessed January 16, 2013.

2. Chow WH, Devesa SS, Warren JL, et al. Rising incidence of renal cell cancer in the United States. JAMA 1999;281:1628-31. http://dx.doi.org/10.1001/jama.281.17.1628

3. Wunderlich $H$, Schumann $S$, Jantitzky V, et al. Increase of renal cell carcinoma incidence in central Europe. Eur Urol 1998;33:538-41. htrp://dx.doi.org/10.1159/000019652

4. Lucas SM, Stern JM, Adibi M, et al. Renal Function Outcomes in Patients Treated for Renal Masses Smaller Than $4 \mathrm{~cm}$ by Ablative and ExtirpativeTechniques. J Urol 2008;179:75-80. http://dx.doi. org/10.1016/i.juro.2007.08.156

5. Asano T, Mizuguchi Y, Horiguchi A, et al. Retroperitoneoscopic partial nephrectomy using radiofrequency coagulation for small renal tumors. Urology 2007;70:869-72. http://dx.doi.org/10.1016/j.urology.2007.07.023

6. Devoe WB, Kercher KW, Hope WW, et al. Hand-assisted laparoscopic partial nephrectomy after 60 cases: comparison with open partial nephrectomy. Surg Endosc 2008;23:1075-80. http://dx.doi. org/10.1007/s00464-008-0135-2

7. Pyo $P$, Chen $A$, Grasso M. Retroperitoneal laparoscopic partial nephrectomy: surgical experience and outcomes. J Urol 2008;180:1279-83. http://dx.doi.org/10.1016/i.juro.2008.06.015

8. Desai P, Andrews P, Ferrigni R, et al. Laparoscopic Partial Nephrectomy at the Mayo Clinic Arizona: Followup Surveillance of Positive Margin Disease. Urology 2007;71:283-6. http://dx.doi.org/10.1016/i. urology.2007.08.050

9. Pavlovich $C P$, Walther $M M$, Choyke PL, et al. Percutaneous radio frequency ablation of small renal tumours: initial results. J Urol 2002;167:10-5. http://dx.doi.org/10.1016/S0022-5347 (05)65371-2

10. Gill IS, Novick AC, Soble JJ, et al. Laparoscopic renal cryoablation: initial clinical series. Urology 1998;52:543-51. http://dx.doi.org/10.1016/50090-4295(98)00309-4

11. Raj GV, Reddan DJ, Hoey MF, et al. Management of small renal tumors with radiofrequency ablation. Urology 2003;61:23-9. http://dx.doi.org/10.1016/S0090-4295(02)01850-2

12. Shingleton WB, Sewell PE. Percutaneous renal tumor cryoablation with magnetic resonance imaging guidance. J Urol 2001;165:773-6. http://dx.doi.org/10.1016/S0022-5347(05)66523-8

13. Yoshimura K, Okubo K, Ichioka K, et al. Laparoscopic partial nephrectomy with a microwave tissue coagulator for small renal tumor. J Urol 2001;165(6 Pt 1):1893-6.

14. Vallancien $\mathrm{G}$, Chartier-Kastler E, Chopin D, et al. Focussed extracorporeal pyrotherapy: experimental results. Eur Urol 1991;20:211-9.

15. Watkin NA, Morris SB, Rivens IH, et al. High-intensity focused ultrasound ablation of the kidney in a large animal model. J Endourol 1997;11:191-6. http://dx.doi.org/10.1089/end.1997.11.191

16. Loffi MA, McCue P, Gomella LG. Laparoscopic interstitial contact laser ablation of renal lesions: an experimental model. J Endourol 1994;8:153-6. http://dx.doi.org/10.1089/end.1994.8.153

17. Gage AA. History of cryosurgery. Semin Surg Oncol 1998;14:99-109. http://dx.doi.org/10.1002/ (SICI) 1098-2388(199803) 14:2<99::AID-SSU2>3.0.C0;2-1

18. Gonder MJ, Soanes WA, Smith V. Experimental prostate cryosurgery. Invest Urol 1964;1:610-9.

19. Onik G, Cobb C, Cohen J, et al. US characteristics of frozen prostate. Radiology 1988;168:629-31.

20. El Dib R, Touma NJ, Kapoor A. Cryoablation versus Radiofrequency Ablation for the Treatment of Renal Cell Carcinoma: a meta-analysis of case series studies. BJU Int 2012;1 10:510-6. http://dx.doi. org/10.1111/j.1464-410X.2011.10885.x

21. Kaouk JH, Aron M, Rewcastle JC, et al. Cryotherapy: clinical end points and their experimental foundations. Urology 2006;68(1Suppl):38-44. http://dx.doi.org/10.1016/j.urology.2005.12.050

22. Rupp CC, Hoffmann NE, Schmidlin FR, et al. Cryosurgical changes in the porcine kidney: histologic analysis with thermal history correlation. Cryobiology 2002;45:167-82. http://dx.doi.org/10.1016/ S0011-2240(02)00125-6

23. Finelli A, Rewcastle $\mathrm{JC}$, Jewett MAS. Cryotherapy and radiofrequency ablation: pathophysiologic basis and laboratory studies. Curr Opin Urol 2003;13:187-91. http://dx.doi.org/10.1097/00042307200305000-00003

24. Hoffmann NE, Bischof JC. The cryobiology of cryosurgical injury. Urology 2002;60(2Suppl1):40-9. http:// dx.doi.org/10.1016/50090-4295(02)01683-7

25. Gupta A, Allaf ME, Kavoussi LR, et al. Computerized Tomography Guided Percutaneous Renal Cryoablation With the Patient Under Conscious Sedation: Initial Clinical Experience. J Urol 2006; 175:447-53. http:// dx.doi.org/10.1016/S0022-5347(05)00247-8

26. Remer EM, Weinberg EJ, Oto A, et al. MR imaging of kidneys after laparoscopic cryoablation. AJR Am J Roentgenol 2000;174:635-40.

27. Gill IS, Remer EM, Hasan WA, et al. Renal cryoablation: outcome at 3 years. J Urol 2005;173:1903-7. http://dx.doi.org/10.1097/01.ju.0000158154.28845.c9

28. $\mathrm{Ng} \mathrm{CK}$, Touma NJ, Chalasani V, et al. The Pattern of Prostate Cancer Local Recurrence after Radiotherapy and Salvage Cryoablation. Can Urol Assoc J 2011;5:125-8. http://dx.doi.org/10.5489/cuaj.09116
29. Wright AD, Turk TM, Nagar MS, et al. Endophytic lesions: a predictor of failure in laparoscopic renal cryoablation. J Endourol 2007;21:1493-6. http://dx.doi.org/10.1089/end.2007.9850

30. Lokken RP, Gervais DA, Arellano RS, et al. Inflammatory nodules mimic applicator track seeding after percutaneous ablation of renal tumors. AJR Am J Roentgenol 2007; 189:845-8. http://dx.doi.org/10.2214/ AJR.07.2015

31. Mouraviev V, Nosnik I, Robertson C, et al. Comparative financial analysis of minimally invasive surgery to open surgery for small renal tumours $<$ or $=3.5 \mathrm{~cm}$ : a single institutional experience. Eur Urol 2007;51:715-21. http://dx.doi.org/10.1016/j.eururo.2006.06.050

32. Chang SL, Cipriano LE, Harshman LC, et al. Cost-Effectiveness Analysis of Nephron Sparing Options for the Management of Small Renal Masses. J Urol 2011;185:1591-7. http://dx.doi.org/10.1016/i. juro.2010.12.100

33. Atwell TD, Farrell MA, Leibovich BC, et al. Percutaneous Renal Cryoablation: Experience Treating 115 Tumors. J Urol 2008;179:2136-41. http://dx.doi.org/10.1016/i.juro.2008.01.144

34. Finley DS, Beck S, Box G, et al. Percutaneous and Laparoscopic Cryoablation of Small Renal Masses. J Urol 2008;180:492-8. http://dx.doi.org/10.1016/i.juro.2008.04.019

35. Georgiades CS, Hong K, Bizzell C, et al. Safety and efficacy of CT-guided percutaneous cryoablation for renal cell carcinoma. J Vasc Interv Radiol 2008;19:1302-10. http://dx.doi.org/10.1016/i.jvir.2008.05.015

36. Hinshaw JL, Shadid AM, Nakada SY, et al. Comparison of percutaneous and laparoscopic cryoablation for the treatment of solid renal masses. AJR Am J Roentgenol 2008;191:1159-68. http://dx.doi. org/10.2214/AJR.07.3706

37. Lehman DS, Hruby GW, Phillips CK, et al. Laparoscopic renal cryoablation: efficacy and complications for larger renal masses. J Endourol 2008;22:1123-7. http://dx.doi.org/10.1089/end.2008.0077

38. Nguyen CT, Lane BR, Kaouk JH, et al. Surgical salvage of renal cell carcinoma recurrence after thermal ablative therapy. J Urol 2008;180:104-9. hittp://dx.doi.org/10.1016/i.juro.2008.03.046

39. Weight CJ, Kaouk JH, Hegarty NJ, et al. Correlation of radiographic imaging and histopathology following cryoablation and radio frequency ablation for renal tumors. J Urol 2008; 179:1277-83. http://dx.doi. org/10.1016/i.juro.2007.11.075

40. Atwell TD, Farrell MA, Callstrom MR, et al. Percutaneous cryoablation of large renal masses: technical feasibility and short-term outcome. AJR Am J Roentgenol 2007a;188:1195-200. http://dx.doi. org/10.2214/AJR.06.1152

41. Atwell TD, Farrell MA, Callstrom MR, et al. Percutaneous cryoablation of 40 solid renal tumors with US guidance and CT monitoring: Initial experience. Radiology 2007b;243:276-83. http://dx.doi. org/10.1148/radiol.2431052133

42. Bandi G, Wen $C$, Hedican SP, et al. Cryoablation of small renal masses: Assessment of the outcome at one institution. BJU Int 2007;100:798-801. http://dx.doi.org/10.1111/i.1464-410X.2007.07158.x

43. Cestari A, Guazzoni G, Buffi NM, et al. Laparoscopic Cryoablation of Small Renal Masses: Technique and Results after 6-Year Experience. Eur Urol 2007;(Suppl 6):646-52.

44. Littrup PJ, Ahmed A, Aoun HD, et al. CT-guided percutaneous cryotherapy of renal masses. J Vasc Interv Radiol 2007;18:383-92. http://dx.doi.org/10.1016/i.jvir.2006.12.007

45. Weld KJ, Figenshau RS, Venkatesh R, et al. Laparoscopic Cryoablation for Small Renal Masses: Three-Year Follow-up. Urology 2007;69:448-51. http://dx.doi.org/10.1016/i.urology.2006.10.030

46. Davol PE, Fulmer BR, Rukstalis DB. Long-term results of cryoablation for renal cancer and complex renal masses. Urology 2006;68(1 Suppl):2-6. http://dx.doi.org/10.1016/i.urology.2006.03.066

47. Hegarty NJ, Gill IS, Desai MM, et al. Probe-ablative nephron-sparing surgery: cryoablation versus radiofrequency ablation. Urology 2006;68(1 Suppl):7-13. http://dx.doi.org/10.1016/j.urology.2005.12.049

48. Lawatsch EJ, Langenstroer $P$, Byrd GF, et al. Intermediate results of laparoscopic cryoablation in 59 patients at the Medical College of Wisconsin. J Urol 2006;175:1225-9. http://dx.doi.org/10.1016/ S0022-5347(05)00682-8

49. Matin SF, Ahrar K, Cadeddu JA, et al. Residual and recurrent disease following renal energy ablative therapy: a multi-institutional study. J Urol 2006;176:1973-7. http://dx.doi.org/10.1016/i.juro.2006.07.016

50. Schwartz BF, Rewcastle IC, Powell T, et al. Cryoablation of small peripheral renal masses: A retrospective analysis. Urology 2006;68(1 Suppl):14-8. http://dx.doi.org/10.1016/i.urology.2006.03.067

51. Desai MM, Aron M, Gill IS. Laparoscopic partial nephrectomy versus laparoscopic cryoablation for the small renal tumor. Urology 2005;66(5 Suppl):23-8. http://dx.doi.org/10.1016/i.urology.2005.06.114

52. Cestari A, Guazzoni G, Dell'Acqua V, et al. Laparoscopic cryoablation of solid renal masses: Intermediate term follow-up. J Urol 2004;172(4 Pt 1):1267-70. http://dx.doi.org/10.1097/01. ju.0000140073.57974.82

53. Gill IS, Novick AC, Meraney AM, et al. Laparoscopic renal cryoablation in 32 patients. Urology 2000;56:748-53. htrp://dx.doi.org/10.1016/S0090-4295(00)00752-4

Correspondence: Dr. Anil Kapoor, McMaster Institute of Urology, McMaster University, St. Joseph's Healthcare, 50 Charlton Ave. East, Hamilton, 0N L8N 4A6; kapoor4@mcmaster.ca 